\title{
Contribution of Tourism and Foreign Direct Investment to Gross Domestic Product: Econometric Analysis in the Case of Sri Lanka
}

\author{
Abdul Majeed MOHAMED MUSTAFA ${ }^{1}$
}

Received: July 21, 2019 Revised: September 16, 2019 Accepted: September 24, 2019

\begin{abstract}
The purpose of the study to evaluate the contribution of foreign direct investment (FDI) and tourism receipts (TR) to Sri Lanka's gross domestic product (GDP). This study employs time series annual data for the period from 1978 to 2016 and EViews 10 econometrics software was used for the time series data analysis. Unit root test was done on the variables and the method chosen was the Augmented Dicky - Fuller test. Co-integration analysis was used for the long run relationship and the Granger causality test was performed to investigate the causal relationship. Recently a more conducive environment has been established after the three decade long ethnic war came to an end. In this context, the Sri Lankan government has taken positive measures to attract foreign direct investment and boost tourism in the country. This study intends to evaluate the contribution of Sri Lanka, as these two factors are considered to be very effective at increasing the GDP of a country. The empirical study shows that there is a positive and statistically significant relationship between the variable's TR and FDI to the GDP in the long run. Results of Granger causality test implied that the two-way causality promoted the economic growth of Sri Lanka.
\end{abstract}

Keywords : Causality, Foreign Direct Investment, Gross Domestic Product, Tourism, Sri Lanka

JEL Classification Code : C22, F21, F43, Z32

\section{Introduction}

FDI and tourism have been broadly accepted as growthenhancing factors in most developing countries. FDI helps the receiving countries to establish much bigger projects in the country than they could by utilizing only their domestic savings. More significantly, FDI is an important mechanism for transferring modern technology and innovation from developed countries to the developing countries. Many analysts express the view that the promotion of FDI inflow into developing economies is an effective solution that could resolve the socio-economic problems faced by host

\footnotetext{
1 First Author and Corresponding Author,Senior Lecturer in Business Economics, Department of Management, Faculty of Management and Commerce, South Eastern University, Sri Lanka. Postal Address: Dr.A.M.M.Mustafa Department of Management, Faculty of Management and Commerce, South Eastern University, Oluvil, \#32360, Sri Lanka] E-mail: amustafa@seu.ac.lk

(c) Copyright: Korean Distribution Science Association (KODISA)

This is an Open Access article distributed under the terms of the Creative Commons Attribution Non-Commercial License (http://Creativecommons.org/licenses/by-nc/4.0/) which permits unrestricted noncommercial use, distribution, and reproduction in any medium, provided the original work is properly cited.
}

countries to a considerable extent (Samimi, Sadeghi, \& Sadeghi, 2011). Tourism is becoming an increasingly attractive development option for many countries of the developing world. In certain countries, it may be the only feasible means of stimulating development. Developing countries are attracted by the potential advantages of tourism, such as increased income through the hospitality trade, foreign exchange earnings, employment generation and economic diversification; nevertheless, these developmental benefits may in fact fail to materialize. After entering this highly competitive global industry, developing countries may find eventually that tourism benefits only the local elite or multinational corporations, or that it is achieved at significant economic cost (Telfer \& Sharpley, 2010). In this backdrop, Sri Lanka is also promoting tourist arrivals and encouraging FDI for the reason that these could play a major role by contributing to the local resource base. Then it will be possible to achieve sufficient rates of economic growth, which will improve the standard of living of the people. In these respects, Sri Lanka offers attractive tourism and investment opportunities and has adopted a number of policies to attract more FDI and increase Tourist Arrivals 
(TA) into the country. This started when Sri Lanka revised its economic policies extensively in 1977 from one of excessive state controls to a much more liberalized and open economy. The objective of the reforms was to attract more FDI and TA into the country.

Due to these progressive measures, Sri Lanka received Rs.24 Million in FDI in 1978, and this figure reached Rs.103,456 Million in FDI in 2012 (Central Bank of Sri Lanka, 2013). By 2017 FDI had more than doubled to Rs.210,361 Million (Central Bank of Sri Lanka, 2018). The tourist arrivals to Sri Lanka too increased dramatically during the post-war period. Sri Lanka has great potential for the development of tourism, and almost 39 places that tourists would find attractive have been identified. Tourist arrivals were 407,511 and 447,890 in 1994 and 2009, respectively. This number increased greatly and doubled in the year 2012, exceeding the One Million mark by touching 1,005,605 (Tourism Development Authority, 2018). In 2017 the figure was 2,116,407 (Tourism Development Authority, 2011). Especially, development in Sri Lanka is taking place rapidly in almost all sectors in the post-war environment. The end of the three-decade long war can bring a prosperous future for the people of Sri Lanka as there are signs of a booming economy and much business activity. Tourism receipts (TR) was Rs. 18,863 million in 2001, 40,133 Million in 2009 and 132,427 Million in 2012 (Central Bank of Sri Lanka, 2013; Tourism Development Authority, 2018). Tourism receipts were Rs. 598,356 million in 2017 (Tourism Development Authority, 2018). In the case of Gross Domestic Product (GDP), there was an increase from Rs.40, 479 Million in 1978 to Rs.13, 317,292 Million in 2017 (Central Bank of Sri Lanka, 2018).

\section{Literature Review}

This section reviews some fundamental ideas to analyze the impact of foreign direct investment and tourism on gross domestic product. Empirically, analyses of the relationship between tourism development and economic growth have been conducted for various countries in different years by employing different methods. Dritsakis (2004) studied the impact of tourism on long-term economic growth in Greece using the Granger causality test and presented the findings in a paper entitled tourism as a long-term economic growth factor. Gross domestic product (GDP), real effective foreign exchange rat-e and international tourism income were used as the applied variables in this study which covered the years 1960-2000. Khalil, Kakar, Waliullah, and Malik (2007) examined the role of tourism receipts in the short-run economic development of Pakistan through error correction mode during 1960-2005. The results revealed that economic expansion is necessary for tourism development in Pakistan. Samimi, Sadeghi, and Sadeghi (2011) Examines the causality and long-run relationship between economic growth and tourism development in some developing countries using the VAR approach during 1995-2009. The findings revealed that there is a bilateral causality and positive long-run relationship between economic growth and tourism development.

Tiwari (2011) examined the impact of tourism receipts, exports and foreign direct investment on economic growth on four Asian countries namely; India, China, Pakistan and Russia. This study titled on "Tourism, Export and FDI as a Means of Growth: Evidence from four Asian Countries" provided lengthy of analysis the impact of tourism receipts and foreign direct investment on economic growth of abovementioned Asian countries. To achieve the research objective, adopted Cobb-Douglas Production function within the neoclassical framework and found that economic growth in four Asian countries is positively impacted by tourism receipt and FDI. Jayathilake (2013) carried out a research dealing with tourism development and economic growth. The research used a model known as a tri-variate model that considered real GDP, international tourist arrivals and real effective exchange rate to investigate the long-run and short-run dynamics of the relationship between tourism and economic growth. The annual time series data were obtained for the period from 1967 to 2011. This study is conducted to determine the contribution of FDI and tourism to economic growth in Sri Lanka. It analyzes the Sri Lankan situation based on the models derived from the review of literature. Many researchers have attempted to investigate the relationship between FDI, Tourism and economic growth in many countries including Sri Lanka. Many of the variables were not captured in the researches done in Sri Lanka. A recent research done in Sri Lanka mainly focuses on the causality, but it leaves out other variables that are used in researches done in other countries when attempting to find out the influence of Foreign Direct Investment and Tourism Industry on the Gross Domestic Product. This research intends to investigate the relationship between FDI and GDP, and TR and GDP econometrically, based on the variables identified in the reviewed literature.

\section{Methodology}

The study uses time series data for the period from 1978 to 2017. Data relevant to this study were collected from secondary sources such as International Financial Statistics (IFS), World Investment Report, Investor's Guide, Central Bank Annual Report 1977-2018, Annual Statistical Report of Sri Lankan Tourism 1990-2018, and Economic and Social Statistics in Sri Lanka 1990-2018. In this study, Econometric Methodology techniques like Multiple Regression and Correlation analysis are used to analyze the data while Ordinary Least Square (OLS) method is used to estimate the parameters of the models. Granger type causality test is used to identify the direction of casual relationship between FDI, tourism and GDP while Unit root test is applied to test the stationary properties of each variable. Co-integration analysis is done to examine the long run (LR) relationship between factors. EViews econometric 
software was used for the data analysis. Variables of the study are Gross Domestic Product (GDP), tourism receipts (TR) as proxy for tourism activity, Foreign Direct Investment (FDI), Economic Freedom Index (EFI) and Dummy variable (D). All of these variables fall into the data type known as quantitative variables, and they can be measured by multiple regression analyses. Dummy variable has been defined as 1 for no war period and 0 for war period.

The following analytical functions given below were used to test the data that were collected to determine the effect of TR and FDI on GDP in Sri Lanka. The model is expressed as follows:

$$
\begin{gathered}
G D P=f(F D I, E F I, T R, D) \ldots \ldots \ldots \ldots \ldots \ldots \ldots \ldots \ldots \\
G D P_{t}=\delta_{0}+\delta_{l} F D I_{t}+\delta_{2} E F I_{t}+\delta_{3} T R_{t}+\delta_{4} D+\varepsilon_{t .}
\end{gathered}
$$

This Model is used to analyze the impact of foreign direct investment and tourism on economic growth. GDP is the Gross Domestic Product, TR is Tourism Receipts, FDI is Foreign Direct Investment, EFI is Economic Freedom Index and D is Dummy variable.

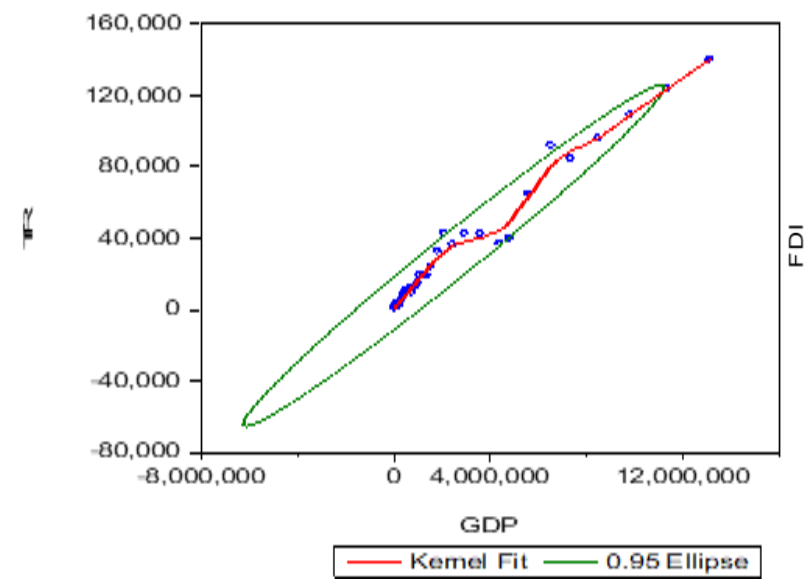

\section{Results and Discussion}

The factors FDI, TR, and GDP play crucial roles in influencing the macro economy of a country. This section explains the use of non-parametric and parametric econometric techniques to evaluate the contribution of each factor. Non-parametric approaches employed are graphical method, Confidence Ellipse, Kernel Fit, and Nearest Neighbor Fit to explore the relationships. Then, parametric econometric techniques like co-integration analysis, error correction model and causality analysis are employed to investigate the relationship fully.

\subsection{Visual Inspection for the Relationship between Variables - GDP: TR and GDP: FDI}

Examining Graphical presentation of data is very useful to identify the trend and underlying relationship between variables. In this case, the Kernel Fit and Confidence Ellipse graphs show there is a strong positive relationship between the variables GDP and TR. They also show that GDP and TR are highly correlated.

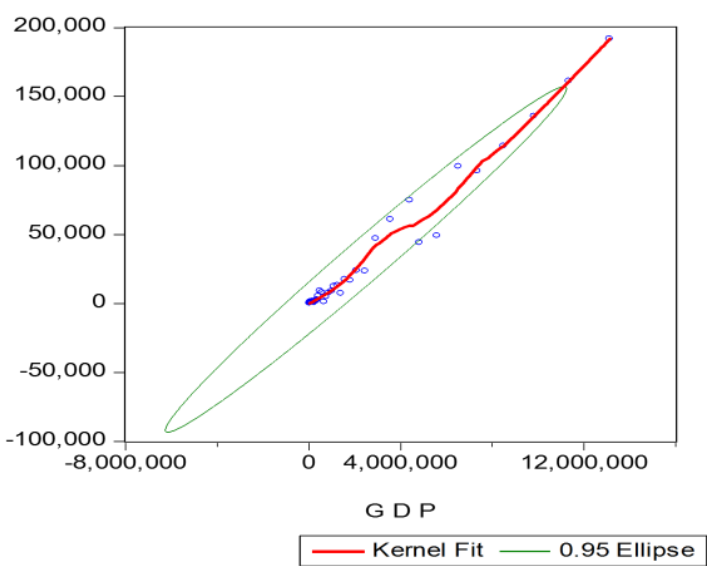

Figure 1: Kernel Fit and Confidence Ellipse- GDP: TR and GDP: FDI

Graphical presentation of data also proves useful to identify the trend and underlying relationship between the variables GDP and FDI. The forecasting model variables Kernel Fit and Confidence Ellipse graphs show that there is a strong positive relationship between GDP and FDI. They also show that the GDP and FDI series are highly correlated.

\subsection{Unit Root Test - Variables GDP, TR, FDI and EFI}

Before the long-run relationship between variables TR, FDI, GDP and EFI can be determined, it is important to carry out unit root analysis. Thus, the first step in our methodology is to determine whether the variables used by the researcher are stationary or non-stationary. If a series is non-stationary, then all the conflicting regression results may turn out to be biased and meaningless, leading to wrong conclusions. 
Table 1: Result of Unit Root Test - GDP, TR, FDI and EFI

\begin{tabular}{|c|l|c|c|c|}
\hline Variables & \multicolumn{1}{|c|}{ ADF Test } & Intercept & Trend \& Intercept & Decision \\
\hline \multirow{2}{*}{ GDP } & Level & -1.66 & -2.62 & Non - Stationary \\
& First difference & $-4.33^{*}$ & $-4.36^{*}$ & Stationary \\
\hline \multirow{2}{*}{ TR } & Level & 3.6 & 1.03 & Stan - Stationary \\
& First difference & $-4.00^{\star}$ & $-5.20^{\star}$ & Stationary \\
\hline \multirow{2}{*}{ FDI } & Level & 3.22 & 1.11 & Non - Stationary \\
& First difference & $-4.84^{*}$ & $-6.17^{\star}$ & Stationary \\
\hline \multirow{2}{*}{ EFI } & Level & -0.96 & -2.35 & Non - Stationary \\
& First difference & $-3.15^{\star *}$ & $-6.74^{*}$ & Stationary \\
\hline
\end{tabular}

* Significant at $1 \% \quad{ }^{* *}$ Significant at $5 \%$

The Augmented Dickey-Fuller (ADF) Unit Root Tests are performed on both levels and the first differences of the variables. The empirical analysis begins with identifying the level of integration of each variable as Regression with nonstationary time series data may lead to spurious results. Thus, the analysis proceeds to the unit root test (Augmented Dickey Fuller) for the variables and the results are presented in Table 1. The Augmented Dickey Fuller Test results confirm that the time series data of the variables in the model are non-stationary in their levels. However, these variables are stationary in their first difference. The results showed that the variables are stationary in the first difference. Results of ADF tests to check if variables are stationary are reported in the table and the null hypothesis of one-unit root against the alternative of stationary cannot be rejected in levels of variables, but is rejected in their first differences. Therefore, variables are integrated of order one, I (1).

\subsection{Unit Root Test for Residual Co-integration Regression Equation for the Model}

The Unit Root Test for Residual Co-integration Regression Equation was performed using the Augmented Dickey-Fuller test as per the Engle-Granger co-integration method. The results obtained were, ADF test statistics = $5.23, \mathrm{P}$ value $=0.0001$. According to the results it can be concluded that the residual is stationary. Variables GDP, TR, FDI, and EFI are co-integrated.

Table 2: Co-integration Regression Results - Dependent Variable: GDP

\begin{tabular}{|c|c|c|c|}
\hline Variable & Coefficient & t Value & Probability $(p)$ \\
\hline (Intercept) & 4109035 & 2.259614 & $0.0304^{\star *}$ \\
\hline Tourist receipts (TR) & 28.94838 & 2.853670 & $0.0073^{*}$ \\
\hline Foreign Direct Investment (FDI) & 40.52314 & 6.566811 & $0.000^{*}$ \\
\hline Economic Freedom Index (EFI) & -60779.29 & -2.271313 & $0.0296^{\star \star}$ \\
\hline Dummy variable $(\mathrm{D})$ & 339406.4 & 1.693026 & $0.0996^{* * *}$ \\
\hline $\begin{array}{l}\text { R-Sq (adj) }=98 \%, \text { F-statistic }=738.74 \\
\text { Prob (F-statistic) }=0.0000\end{array}$ & & & \\
\hline
\end{tabular}

The long-run estimate of the equation is as follows:

$$
\begin{aligned}
G D P_{t}= & 4109035+40.52314 F D I_{t}-60779.29 E F I_{t}+ \\
& 28.94838 T R_{t}+339406.4 D++\varepsilon_{t}
\end{aligned}
$$

According to Table 2, the adjusted is very high, but the Akaike info criterion, Schwarz criterion, F-statistic, and Prob (F-statistic) are appropriate. As per the model when researcher turns into the coefficient of determination, all the independent variables jointly explain $98 \%$ of the total variation in GDP; this means the model is statistically appropriate to measure the relationship between economic performance and factors that affect the economic performance, especially receipts from tourism and foreign direct investment. The overall significance of the model is at $1 \%$ level. According to the long run regression output results presented in the table, all the signs of the coefficients of variables are as theoretically expected. Further, the estimated coefficient of TR indicates that a 1 million increase in TR will increase GDP by 28.94 million. The long run relationship between TR and GDP has been positive and statistically significant at the $1 \%$ level. The estimated coefficient of FDI indicates that a 1 million increase in FDI will increase GDP by 40.52 million. The long run relationship between FDI and GDP has been positively and statistically significant at the $1 \%$ level. However, it reveals that the actual impact of FDI can be no time lag of this forecasting model. Economic Freedom Index has a negative coefficient but is statistically significant at the $5 \%$ level. The dummy variable used to indicate the war and non-war periods in this study is positively and statistically significant at the $10 \%$ level and it helps to determine GDP in the long run.

According to the error correction model results (Table 3), the adjustment speed coefficient of the error correction term is statistically significant and has a negative sign. The negative sign indicates that the GDP moves downward towards the equilibrium path. It implies that $76 \%$ of the disequilibrium is corrected each year. This shows the downward adjustment of GDP towards the equilibrium path occurs within the 
period of one year.

Table 3: Results of Error Correction Model (ECM): Dependent Variable: D (GDP)

\begin{tabular}{|c|c|c|c|}
\hline Variable & Coefficient & $\mathbf{t}$ Value & Probability (p) \\
\hline ( Intercept ) & 35073.28 & 0.575287 & 0.5691 \\
\hline $\mathrm{D}(\mathrm{TR})$ & 46.54556 & 3.937162 & $0.0004^{\star}$ \\
\hline $\mathrm{D}(\mathrm{FDI})$ & 11.77597 & 2.373068 & $0.0238^{\star *}$ \\
\hline $\mathrm{D}(\mathrm{EFI})$ & -37131.16 & -1.141955 & 0.2619 \\
\hline $\mathrm{D} 01$ & 179984.5 & 1.637380 & 0.1113 \\
\hline RESID01(-1) & -0.765691 & -4.181899 & $0.0002^{\star}$ \\
\hline
\end{tabular}

${ }^{*}$ Significant at $1 \% \quad{ }^{* *}$ Significant at $5 \%$

However, the short run impact multiplier of TR and FDI are statistically significant at the $1 \%$ and $5 \%$ levels, respectively and have the expected sign. EFI and D variables are statistically not significant and have the expected sign in the short run period in Sri Lanka.
Table 4: Granger Causality Tests (GDP: TR)

\begin{tabular}{|c|c|c|c|c|}
\hline $\begin{array}{c}\text { Null } \\
\text { Hypothesis }\end{array}$ & Obs & F-Statistic & P-Value & $\begin{array}{c}\text { Granger } \\
\text { Causality }\end{array}$ \\
\hline $\begin{array}{c}\text { TR does not } \\
\text { Granger } \\
\text { Cause GDP }\end{array}$ & 35 & 5.51439 & 0.0024 & Yes \\
\hline $\begin{array}{c}\text { GDP does not } \\
\text { Granger } \\
\text { Cause TR }\end{array}$ & 35 & 19.0146 & $2 . E-07$ & Yes \\
\hline
\end{tabular}

The results shown in Table 4 reveal that the causality does run from tourism receipts to economic growth in Sri Lanka. According to the Granger Causality Tests, TR statistically $(\mathrm{p}$ value $=0.0024)$ motivated GDP and GDP statistically $(\mathrm{p}$ value $=2 . \mathrm{E}-07)$ motivated TR. The results show that there are two-way causal relationships from TR to GDP and from GDP to TR in Sri Lanka.

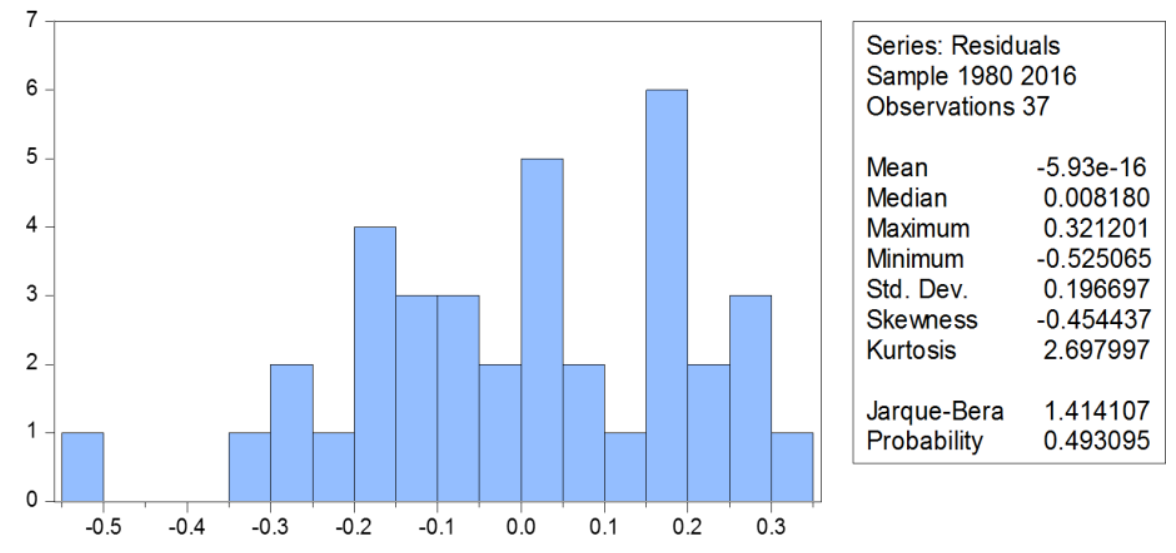

Figure 2: Residual Distribution Model

The JB test shows that in Figure 3 the residual is normally distributed.

Table 5: The results of diagnostic tests based on the Model

\begin{tabular}{|c|c|c|c|}
\hline Tests & \multicolumn{2}{|c|}{ Statistics } & Probability \\
\hline Jarque-Bera (normality test) & \multicolumn{2}{|c|}{1.414107} & 0.493095 \\
\hline Heteroskedasticity Test: ARCH & $\begin{array}{l}\text { F statistics } \\
\text { ObsR-squarec }\end{array}$ & $\begin{array}{l}0.181355 \\
0.191004\end{array}$ & $\begin{array}{l}0.6729 \\
0.6621\end{array}$ \\
\hline Bruesh-Godfrey Serial Correlation LM test & $\begin{array}{l}\text { F-statistics } \\
\text { ObsR-squarec }\end{array}$ & $\begin{array}{l}1.657941 \\
15.90066\end{array}$ & $\begin{array}{l}0.1550 \\
0.1025\end{array}$ \\
\hline
\end{tabular}

The above (Table 5) show that the model in the study has no non-normality errors, no autocorrelation, no heteroskedasticity, has a well specified functional form and stable regressions. Therefore, it can be concluded that the model applied in the study is robust and the specification of the model is an adequate representation of the data.

Cumulative sum (Figure 3) and Cumulative sum of squares test using recursive residuals were performed to examine the stability of the long run parameters. As the plots of the statistics for both tests lie within the critical bounds set for the 5 percent level, the hypothesis that regression equation is correctly specified is not rejected. It proves parameter stability. Residual diagnostics concerning autocorrelation, heteroskedasticity and normality indicate that the results are robust. 

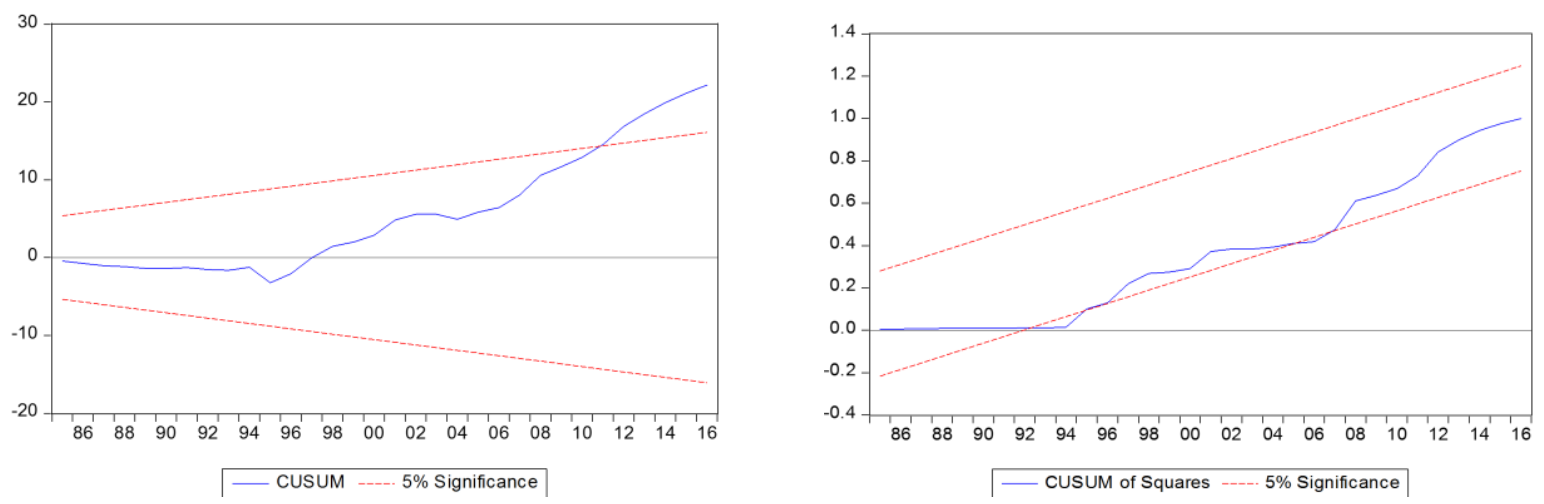

Figure 3: Stability Test Cusum and Cusum of squares of Model

\section{Conclusion}

Sri Lanka's liberalization and deregulation policies put into effect in 1977 have attracted a huge volume of foreign direct investments into the country. However, the protracted civil war affected the country's economic base and resulted in poor performance. In Sri Lanka, more conducive environment has been established after the three decade long ethnic war came to an end. In this context, the Sri Lankan government has taken positive measures to attract foreign direct investment and boost tourism in the country. For the model, the parametric econometric technique - Cointegration analysis was used for achieving the objective of the study. As for the performance of TR to GDP and FDI to GDP forecasting model, the co-integration regression results revealed that the relationship between TR and GDP was positive and statistically significant at the $1 \%$ level. Relationship between FDI and GDP was positive and statistically significant at the $1 \%$ level. However, it reveals that the actual impact of FDI can have no time lag in this model. According to the results of the Granger Causality tests, the model indicates two-way causal relationships. At present, the government policies also focus on increasing tourist arrivals in the country and facilitating investments in tourism infrastructure; these measures would lead to a significantly higher multiplier effect on the key economic parameters of the Sri Lankan economy. Despite several other measures taken by the government, they have not proven sufficient for the industry to compete with other international destinations. It must be further noted that Sri Lanka has to take actions to improve the quality of infrastructure, facilitation services, ensure product quality and utilize modern marketing and publicity tools to be competitive in the global tourism industry. Hence, it is imperative that the government aggressively undertake some marketing efforts to promote the tourism sector and turn Sri Lanka into a leading tourist destination in Asia.

\section{References}

Central Bank of Sri Lanka. (2013). Economics and social statistics of Sri Lanka. Colombo, Sri Lanka: Central Bank of Sri Lanka.

Central Bank of Sri Lanka. (2018). Economics and social statistics of Sri Lanka. Colombo, Sri Lanka: Central Bank of Sri Lanka.

Telfer, D. J., \& Sharpley, R. (2010). Tourism and development in the developing world. New York, NY: Routledge.

Dritsakis, N. (2004). Tourism as a long-run economic growth factor: An empirical investigation for Greece using causality analysis. Tourism Economics, 10(3), 305316.

Jayathilake, P. M. B. (2013). Tourism and economic growth in Sri Lanka: Evidence from cointegration and causality analysis. International Journal of Business, Economics and Law, 2(2), 22-27.

Khalil, S., Kakar, M. K., \& Waliullah. (2007). Role of tourism in economic growth: Empirical evidence from Pakistan economy. The Pakistan Development Review, 46(4), 985-995.

Samimi, A. J., Sadeghi, S., \& Sadeghi, S. (2011). Tourism and Economic Growth in Developing Countries: P-VAR Approach. Middle-East Journal of Scientific Research, 10(1), 28-32.

Tourism Development Authority. (2011). Annual report. Retrieved January 12, 2018, from https://en.wikipedia.org/wiki/Tourism_in_Sri_Lanka

Tourism Development Authority. (2018). Annual report. Retrieved March 9, 2019, from http://www.sltda.lk/monthly-tourist-arrivals-reports-2019

Tiwari, A. K. (2011). Tourism, exports and FDI as a means of growth: Evidence from four Asian countries. The Romanian Economic Journal, XIV (40), 131-151. 